Review

Author(s): W. S.

Review by: W. S.

Source: The Irish Church Quarterly, Vol. 1, No. 3 (Jul., 1908), pp. 240-241

Published by:

Stable URL: http://www.jstor.org/stable/30066901

Accessed: 20-01-2016 13:04 UTC

Your use of the JSTOR archive indicates your acceptance of the Terms \& Conditions of Use, available at http://www.jstor.org/page/ info/about/policies/terms.jsp

JSTOR is a not-for-profit service that helps scholars, researchers, and students discover, use, and build upon a wide range of content in a trusted digital archive. We use information technology and tools to increase productivity and facilitate new forms of scholarship. For more information about JSTOR, please contact support@jstor.org. 
is rightly anxious that the best available text of the New Testament should be in common use, and one cannot help sharing his wonder at the general acquiescence of the Christian world in the so-called Textus Receptus. "It is singular to see a man anxious to have the latest and best thing in electric lights, but totally indifferent as to having the best text in his New Testament."

\section{THE NEW THEOLOGY AND THE OLD RELIGION.} By the Right Rev. Charles Gore, D.D. (Murray.) $5^{s}$. net.

This volume suffers from the disadvantage of having its substnace presented in two forms, as lectures and as sermons, with considerable repetitions which might easily have been avoided. We cannot help thinking that when Bishop Gore re-wrote the Lectures which form the first part of his book, and which deal expressly with what is called the New Theology, he would have dcne well to have incorporated with them whatever of the Sermons relates to that subject. The rest of the volume, particularly the part dealing with the Church and the poor, and with economic questions, might better have been published separately, and have given a more complete treatment of those subjects.

At the same time the Lectures contrasting the New Theology with the Old Religion are of great value. The contrast in the title is carried on throughout. It implies that the New Theology has essentially an intellectual or academic source in certain supposed intellectual requirements, while the Old Religion is the answer of God in Christ to the practical needs of the common life of humanity in the matter of Religion. The New Theology professes to be based on the new view by which, according to it, science has superseded the old-fashioned ideas of God, of sin, of Christ, and of nature. At the same time, Bishop Gore draws a distinction between this view, as expressed by men of science like Sir Oliver Lodge, and by theologians like the Rev. R. J. Campbell. In the case of men of science it expresses an advance from their old position. In the case of theologians it is a reversion to ideas which oppose the Christianity of the Creeds. The New Theology is not a true development or evolution from what went before, but a different type of religion altogether. To those who believe in Evolution, this of itself ought to constitute a presumption against it.

For the Christian doctrine of God it substitutes the Stoic doctrine of Immanence which, however true in itself, is, 
when coupled with a denial of the Divine Personality and transcendence, not to be distinguished from a scheme in which "God is all, and all is God."

For the Christian doctrine of sin, as lawlessness, having its seat in the will, it substitutes the notion that $\sin$ is a necessary condition of the inevitable progress of humanity upwards; that its seat is in the animal nature; and that it is rather to be lamented and compassionated than blamed, the mad pursuit of sin being at bottom but a mistaken form of the Psalmist's aspiration:- "As the hart panteth after the waterbrooks, so panteth my soul after Thee, $O$ God."'

For the Christian doctrine of Christ, as God in a sense in which no other man can be, it substitutes the view that God is manifest in Christ only in a superior degree to that in which $\mathrm{He}$ is manifested in other men-that all men are potentially Christs, and Christ is only the highest point of human evolution, instead of being, as St. Paul teaches, the starting-point of a new creation in which alone humanity attains its perfect spiritual development.

It will be seen that in all these points this theory hangs together, and is practically what it professes to be, a "New Theology," if that can be called a theology which knows no personal God, and confounds Him with the world and the world with Him. And this accounts for the ambiguous position taken by some of its adherents in respect to miracles. In certain cases they admit them as a form of "moral therapeutics"; but logically, for the New Theology, there can be no miracles, no Virgin Birth, no resurrection, though the evidence for the fact of the resurrection is so great that some at least feel a difficulty in denying it. 'And yet without the hope that is based on the resurrection, what prospect lies before the human race? " Science," as Bishop Gore truly says, "strictly speaking, has no Gospel. It affords us no assurance whatever against the deterioration of our race, or its extinction." And it appears that the New Theology, so far as it is based on science-and on what else can it be based?-must be in the same predicament. It is to be regretted that the Lectures before us do not compare the New Theology and the Old Religion in their eschatology, and leave unnoticed their respective teachings as to the ultimate destiny of humanity.

Want of space compels us to confine our remarks to the treatment of the New Theology, but we specially commend to thoughtful men the Sermon entitled "The Church and the Poor," which deals with the treatment of our Lord's teaching about wealth by the Church of the present age.

${ }^{1}$ New Theology Sermons, p. 183. 